\title{
Physicochemical Characteristics, Degradation Rate and Vulnerability Potential of Obudu Cattle Ranch Soils in Southeast Nigeria
}

\author{
A. U. Akpan-Idiok ${ }^{*}$, K. I. Ofem
}

Department of Soil Science, University of Calabar, Cross River State, Nigeria.

Email: *ackleyaidiok@yahoo.com

Received October $14^{\text {th }}, 2013$; revised November $14^{\text {th }}, 2013$; accepted November $21^{\text {st }}, 2013$

Copyright (C) 2014 A. U. Akpan-Idiok, K. I. Ofem. This is an open access article distributed under the Creative Commons Attribution License, which permits unrestricted use, distribution, and reproduction in any medium, provided the original work is properly cited. In accordance of the Creative Commons Attribution License all Copyrights (C) 2014 are reserved for SCIRP and the owner of the intellectual property A. U. Akpan-Idiok, K. I. Ofem. All Copyright (C) 2014 are guarded by law and by SCIRP as a guardian.

\begin{abstract}
Obudu Cattle Ranch covers an area of 2400 hactares at an altitude of 900 - $1500 \mathrm{~m}$ above mean sea level and is suitable for cultivation of cucumber (Cucumis sativus), tomato (Solanum lycopersicum), Irish potato (Solanum tuberosum), spinach (Spinacia oleracea) cabbage (Brassica oleracea), lettuce (Lactuca sativa) because of its semitemperate climate. Physicochemical characteristics, degradation rates and vulnerability potential of the soils were studied. Eighteen composite soil samples $(0-15$ and $15-30 \mathrm{~cm})$ were collected at interval of $500 \mathrm{~m}$ along North-South and East-West transects in nine locations. The soils were characterized as follows: texture of sandy loam for the surface and subsurface soils; $\mathrm{pH}_{(\mathrm{H} 20)}\left(4.7\right.$ - 5.7), organic carbon $\left(4.9\right.$ - $\left.74.8 \mathrm{gkg}^{-1}\right)$, total nitrogen $(0.2$ $\left.4.8 \mathrm{gkg}^{-1}\right)$, carbon-nitrogen ratio (14 - 25), available $P\left(6.66\right.$ - $\left.107.89 \mathrm{mgkg}^{-1}\right)$, effective cation exchange capacity (ECEC) $\left(5.58-14.62 \mathrm{cmol} \cdot \mathrm{kg}^{-1}\right)$ and base saturation $(49.37 \%-85.28 \%)$; the surface soils were generally higher in organic carbon, total nitrogen, available $P$ and ECEC than the subsurface. The Soil Degradation Rate (SDR)/ Vulnerability Potential ( $\mathrm{Vp}$ ) weighted values of texture (3/3), soil $\mathrm{pH}_{(\mathrm{H} 2 \mathrm{O})}(4 / 2)$, organic carbon $(1 / 5)$ and base saturation (2/4) showed moderate to low susceptibility of the soils to degradation or vulnerability. The soils could be managed by liming, practicing crop rotation and using soil conservative measures.
\end{abstract}

\section{KEYWORDS}

Physicochemical Characteristics; Obudu Cattle Ranch; Soil Degradation; Vulnerability Potential

\section{Introduction}

Obudu Cattle Ranch covers an area of $24 \mathrm{~km}^{2}$ at an altitude of 900 - $1500 \mathrm{~m}$ Above Sea Level in a hilly and mountainous region of Northern Cross River, Nigeria [1]. Exploration of the ranch took place in 1949, while McCaugley started its development in 1951. At present, the Cross River State government has turned the ranch into a world well-known and tourist resort centre in Nigeria. It is otherwise known as Obudu Mountain Resort. The basement complex of Obudu Cattle Ranch consists of Precambrian migmatites, gneisses and Schists with intrusive igneous rocks such as granodiorite, diorite, gabbro and dolerite $[2,3]$. This study therefore focuses on the soils'

\footnotetext{
${ }^{*}$ Corresponding author.
}

particle size distribution, $\mathrm{pH}_{(\mathrm{H} 2 \mathrm{O})}$, organic carbon, basic cations, available $\mathrm{P}$, base saturation and cation exchange capacity. The productivity of the soils under agricultural management systems was evaluated through the soil degradation rate (SDR) and vulnerability potential (Vp) [4, 5].

Studies have reported that most soils on Plateau are not well developed in most African countries and even in Southern Asian countries [6]. However, soils of Mambilla Plateau in Nigeria are well developed with deep profiles $(>100 \mathrm{~cm})$ and colour variation between red and yellow for soils developed from Basement Complex rocks. Those developed on Basaltic rocks are reddish brown to yellowish red and coarse to fine in texture with considerable amounts of sand (>60\%) and clay (>20\%) [1,6]. Si- 
milarly, the soils of Obudu Cattle Ranch are deep ( $>150$ $\mathrm{cm}$ ) with colour variation of dark brown silt, loam or gravelly loamy sand surface over very dark grey sandy loam, loam or loamy sand subsurface. The soils are further characterized by coarse texture, low contents of organic carbon $(0.93 \%)$, cation exchange capacity and clay (15\%) [1].

The soils of Obudu Cattle Ranch are used for the cultivation of cucumber, tomato, Irish potato, spinach and tea $[7,8]$. This is because its semi-temperate climate supports the growth of these crops. Others are forages (Alfalfa), cereals (wheat, sorghum), vegetables (cabbage and lettuce), cotton and peanuts. The livestock industry has also recorded a huge success in the ranch as it encourages dairy products. With conversion of the ranch to mountain resort which attracts tourists from all over the world, most of the land used for agriculture will be encroached into and the rate of degradation enhanced. There is therefore need to study the physicochemical characteristics, Soil Degradation Rate (SDR) as well as vulnerability potential (Vp) of the Obudu Cattle Ranch soils and also suggest ameliorative measures for improved productivity of the soils.

\section{Materials and Methods}

\subsection{Description of the Study Area}

Obudu Cattle Ranch Resort (6 $6^{\circ} 15^{\prime} \mathrm{N} ; 6^{\circ} 30^{\prime} \mathrm{N}$ and $9^{\circ} 15^{\prime} \mathrm{E}$; $9^{\circ} 30^{\prime} \mathrm{E}$ ) is located in Northern Cross River State, Nigeria (Figure 1). It constitutes the highest elevated part of south-eastern Nigeria with a maximum height of $1576 \mathrm{~m}$ above sea level [3,9]. The soils of the area are underlain by Precambrian Schists and gneisses with intrusive of igneous rocks such as granodiorite, diorite, gabbro and dolerite [2]. The topography of the land scape is rugged with north-easterly trending ridges separated by low lands which form valleys and passes [3]. The climate of Obudu Cattle Ranch (Obudu Mountain Resort) has characteristics of temperate region though is found in tropical region. It has a mean rainfall of $2000-3100 \mathrm{~mm} /$ annum and temperature of $15^{\circ} \mathrm{C}-23^{\circ} \mathrm{C}[3,10]$. The vegetation types in the study area are Guinea savanna and montanne vegetation. Tall grasses are interspersed with trees, while riparian forests with tall trees occupy river valleys. Among trees in the Guinea savanna area include acacias, baobab and shea-butter [3].

\subsection{Soil Sampling}

Eighteen composite soil samples were collected at the depths of $0-15 \mathrm{~cm}$ and $15-30 \mathrm{~cm}$ from nine locations along North-South and East-West directions at $500 \mathrm{~m}$ interval of Obudu Cattle Ranch, Obanliku Local Government Area of Cross River State, Nigeria (Figure 1). Each composite soil sample was stored in a well labelled polyethylene bag and transported to the laboratory for analysis.

\subsection{Laboratory Analysis}

Soil samples were air-dried and sieved through a $2 \mathrm{~mm}$ mesh. Particle size analysis was carried out by hydrometer method [11] using sodium hexametaphosphate as dispersant. Soil $\mathrm{pH}$ was determined in soil-water ratio of 1:2.5 using a glass electrode $\mathrm{pH}$ meter. Organic carbon was determined by the Walkley and Black, 1934 [12] method, while total nitrogen was by the Kjeldahl digestion method [11]. Available phosphorus was determined by the Bray and Kurtz, 1945 [13] No. 1 method. Exchangeable bases (Ca, $\mathrm{Mg}, \mathrm{K}$ and $\mathrm{Na}$ ) were extracted in $1 \mathrm{~N}$ $\mathrm{NH}_{4} \mathrm{OAc}$ at $\mathrm{pH}$ 7. Potassium and sodium were determined with a flame photometer, while $\mathrm{Ca}$ and $\mathrm{Mg}$ were determined by the EDTA titration method [14]. Exchangeable acidity was by titration method using IN $\mathrm{KCl}$ extract [15]. Effective cation exchange capacity was a summation of exchangeable bases (Ca, Mg, $\mathrm{K}$ and $\mathrm{Na}$ ) and exchangeable acidity. Percent base saturation was obtained by dividing the total exchangeable bases ( $\mathrm{Ca}, \mathrm{Mg}, \mathrm{K}$ and $\mathrm{Na}$ ) by the ECEC.

\subsection{Soil Degradation Rating (SDR)/Vulnerability Potential (Vp)}

The rating scheme for soil degradation developed by Lal, 1993 [4] for soil physicochemical properties, namely: texture, $\mathrm{pH}$, total nitrogen, organic carbon, available $\mathrm{P}$, effective cation exchange capacity and base saturation were used in this study. The vulnerability potential of these properties was also determined. For the SDR, the weighting sequence was as follows: $1=$ none, 2 = slight, 3 = moderate, $4=$ severe and $5=$ extreme. In this way, good soils have the lowest SDR and poor soils the highest value. For the $\mathrm{Vp}$, the weighting was the reverse such that: $5=$ very low, $4=$ low, $3=$ medium, $2=$ high and $1=$ very high $[4,5]$.

\subsection{Statistical Analysis}

The data collected were analysed using descriptive statistics (mean and range) with the help of Genstat software.

\section{Results and Discussion}

\subsection{Particle Size Distribution}

Sand fraction ranged from 605.4 - $845.4 \mathrm{gkg}^{-1}$ with a mean of $725.5 \mathrm{gkg}^{-1}$ in the soils (Table 1). Silt fraction varied between 66.2 - $241.6 \mathrm{gkg}^{-1}$ with a mean of 190.48 $\mathrm{gkg}^{-1}$ while clay fraction ranged from $41.8-269.2 \mathrm{gkg}^{-1}$ with a mean of $84 \mathrm{gkg}^{-1}$ in the soils. The soils are coarse 


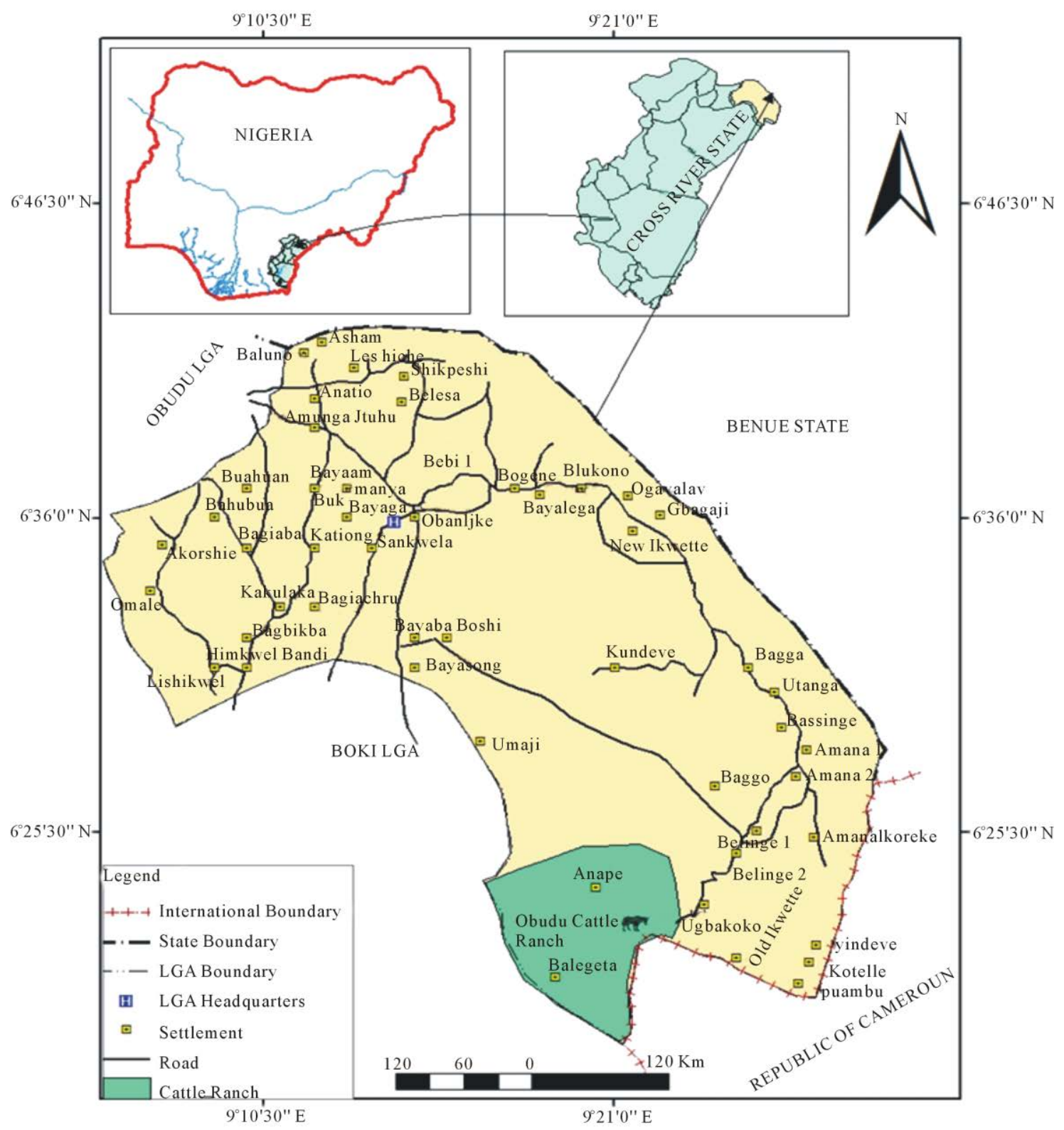

Figure 1. Map of cross river state showing Obanliku local government area.

textured with a high content of sand in surface and subsurface layers exceeding $700 \mathrm{gkg}^{-1}$, giving a dominant textural class of sandy loam. Similar results were obtained for the Obudu Cattle Ranch soils [16]. Such soils lack adsorption capacity for basic plant nutrients and water.

\subsection{Chemical Characteristics}

The soil $\mathrm{pH}\left(\mathrm{H}_{2} \mathrm{O}\right)$ ranged from 4.7 - 5.7 with a mean of 5.1 (Table 2), indicating that the soils are strongly acid in reaction. The acidic conditions might be due to the high rainfall that exceeds $2000 \mathrm{~mm}$ /annum and sandy nature of the soils. The electrical conductivity values varied from $0.039-0.105 \mathrm{dSm}^{-1}$ with a mean of $0.063 \mathrm{dSm}^{-1}$. This indicates that the soils are non-saline. Organic carbon contents ranged from $4.9-74.8 \mathrm{gkg}^{-1}$ with a mean of $43.09 \mathrm{gkg}^{-1}$. This level of organic carbon is rated high as most values are higher than $15 \mathrm{gkg}^{-1}$ [17]. Total nitrogen varied between 0.20 and $4.80 \mathrm{gkg}^{-1}$ with a mean value of $2.54 \mathrm{gkg}^{-1}$; this range of value is rated medium for most soils when compared with the range $2-5 \mathrm{gkg}^{-1}$ for productive soils [17]. Available $\mathrm{P}$ varied from 6.66 to $107.89 \mathrm{mgkg}^{-1}$ with a mean of $22.14 \mathrm{mgkg}^{-1}$ for surface and subsurface soils. This range of values is high exceeding $15 \mathrm{mgkg}^{-1}$ regarded for productive soils [5,18]. Exchangeable bases were as follows: Ca $\left(1.7-7.95 \mathrm{cmol} \cdot \mathrm{kg}^{-1}\right)$, 
Table 1. Particle size distribution of Obudu Cattle Ranch soils in Cross River State, Nigeria.

\begin{tabular}{|c|c|c|c|c|c|}
\hline Sample Location & Depth (cm) & Sand $\left(\mathrm{gkg}^{-1}\right)$ & Silt $\left(\mathrm{gkg}^{-1}\right)$ & Clay $\left(\mathrm{gkg}^{-1}\right)$ & Texture \\
\hline \multirow[t]{2}{*}{ Ranch Bottom I } & $0-15$ & 745.4 & 186.2 & 68.4 & sl \\
\hline & $15-30$ & 745.4 & 186.2 & 68.4 & sl \\
\hline \multirow[t]{2}{*}{ Ranch Bottom II } & $0-15$ & 645.4 & 166.2 & 188.4 & sl \\
\hline & $15-30$ & 845.4 & 86.2 & 68.4 & ls \\
\hline \multirow[t]{2}{*}{ Ranch Reference Point } & $0-15$ & 741.2 & 207 & 51.8 & sl \\
\hline & $15-30$ & 721.2 & 227 & 51.8 & ls \\
\hline \multirow[t]{2}{*}{ Ranch South I } & $0-15$ & 712.8 & 228 & 59.2 & sl \\
\hline & $15-30$ & 708.7 & 238.9 & 52.4 & ls \\
\hline \multirow[t]{2}{*}{ Ranch South II } & $0-15$ & 713.4 & 228 & 58.6 & sl \\
\hline & $15-30$ & 765.4 & 106.2 & 128.4 & sl \\
\hline \multirow[t]{2}{*}{ Ranch North I } & $0-15$ & 712.3 & 237.8 & 49.9 & sl \\
\hline & $15-30$ & 716.6 & 241.6 & 41.8 & sl \\
\hline \multirow[t]{2}{*}{ Ranch West I } & $0-15$ & 721.5 & 218.6 & 59.9 & sl \\
\hline & $15-30$ & 725.5 & 224.6 & 49.9 & sl \\
\hline \multirow[t]{2}{*}{ Ranch West II } & $0-15$ & 729.2 & 219.8 & 51.0 & sl \\
\hline & $15-30$ & 718.4 & 234.8 & 46.8 & sl \\
\hline \multirow[t]{2}{*}{ Ranch West III } & $0-15$ & 605.4 & 125.4 & 269.2 & sl \\
\hline & $15-30$ & 785.4 & 66.2 & 148.4 & sl \\
\hline Surface Range & & $605.4-745.5$ & $125.4-237.8$ & $49.9-269.2$ & \\
\hline Surface Mean & & 702.96 & 201.89 & 95.15 & sl \\
\hline Subsurface Range & & 708.7 - 845.4 & $66.2-241.6$ & $41.8-148.4$ & \\
\hline Subsurface Mean & & 748.0 & 179.08 & 72.92 & sl \\
\hline Overall Range & & $605.4-845.4$ & $66.2-241.6$ & $41.8-269.2$ & \\
\hline Overall Mean & & 725.5 & 190.48 & 84.0 & sl \\
\hline
\end{tabular}

sl = Sandy loam; ls = Loamy sand.

Mg (1 - $\left.3.04 \mathrm{cmol} \cdot \mathrm{kg}^{-1}\right), \mathrm{K}\left(0.08-0.89 \mathrm{cmol} \cdot \mathrm{kg}^{-1}\right)$ and $\mathrm{Na}\left(0.06-0.11 \mathrm{cmol} \cdot \mathrm{kg}^{-1}\right)$. These values are moderate when compared with the acceptable limits of individual basic cations for crop production in the ecological zone. Effective cation exchange capacity (ECEC) values were moderate to high $\left(5.58-14.62 \mathrm{cmol} \cdot \mathrm{kg}^{-1}\right)$ as established by FPDD, 1990 [18] for productive soils. With mean percentage base saturation of 65, basic nutrients must have occurred in available forms in soil solution for plant uptake.

\subsection{Mineralization/Nutrient Availability Ratios}

Carbon-Nitrogen Ratio
Values of carbon-nitrogen ratio were low (range, 14 25 ) as all the values were less than the separating index of 25 [19] (Table 1) for mineralization and immobilization of nitrogen in soils. This ratio indicates high levels of microbial activity, increased decomposition of organic matter and corresponding release of nutrient elements into the soil solution for plant nourishment.

\section{Magnesium-Potassium (Mg:K) Ratio}

The ratios of $\mathrm{Mg}: \mathrm{K}$ were high (2.8 - 20.5) when compared with a critical level of 1:2 for productive soils [20]. $\mathrm{Mg}$ in the form of $\mathrm{Mg}^{2+}$ is more likely to be available to crop plants in the soil relative to $\mathrm{K}$. It is a vital element in the formation of chlorophyll, aids in the translocation of 

of Obudu Cattle Ranch Soils in Southeast Nigeria

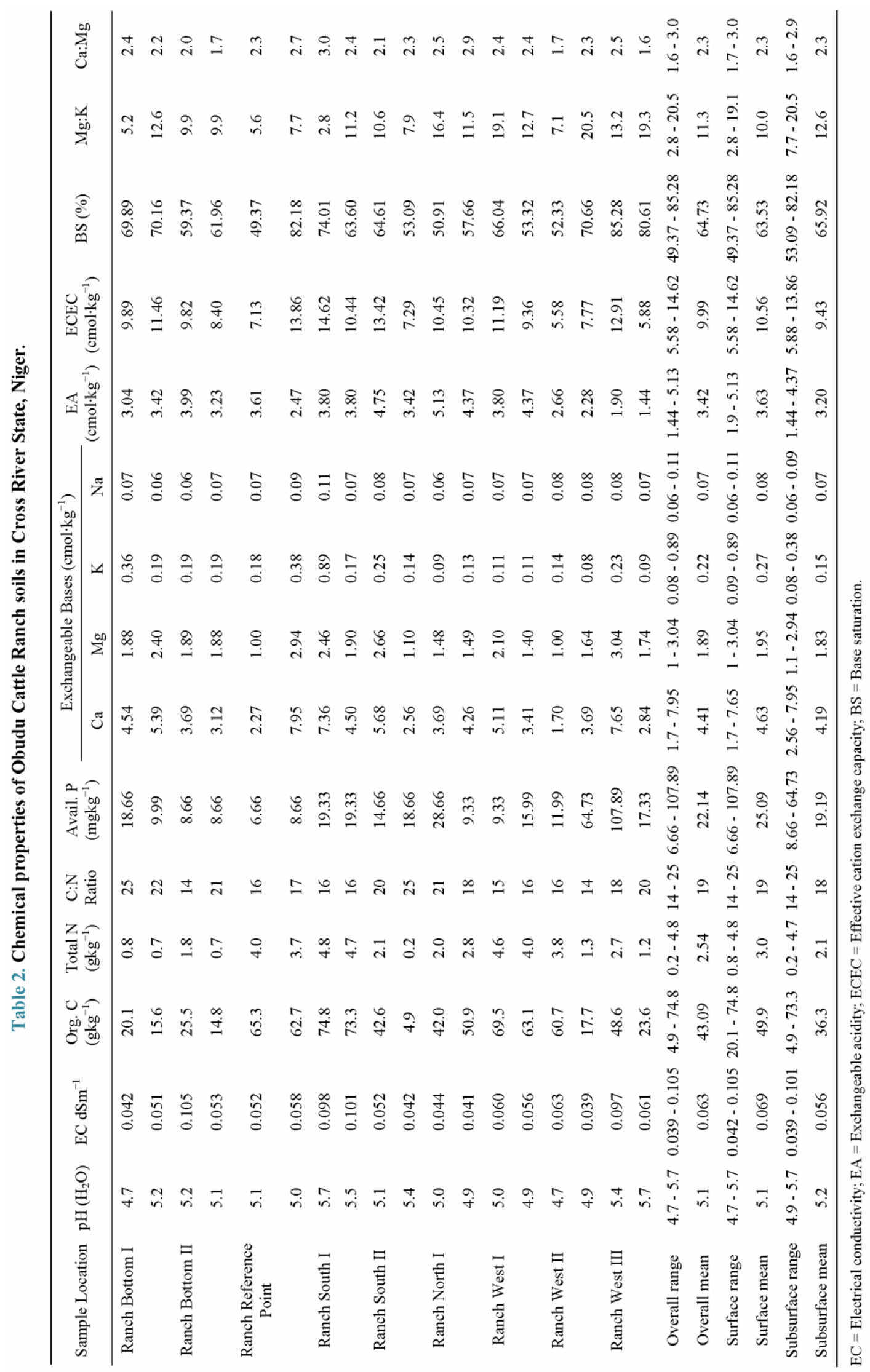


starch within plant, and is essential for the formation of oils and fats. Potassium is absorbed by crop plants as $\mathrm{K}^{+}$. It improves plant's ability to resist disease and cold, aids in the production of carbohydrates and proteins and an active part of plant enzyme systems [5,21].

\section{Calcium-Magnesium (Ca:Mg) Ratio}

The Ca:Mg rates were low (range, 1.6 to 3.0) when compared with a normal range of $3: 1$ to $5: 1$ for productive soils [20]. This indicates that the soils have low amounts of $\mathrm{Ca}$ with considerable amount of $\mathrm{Mg}$ in the soil solution. Calcium is absorbed by plants as $\mathrm{Ca}^{2+}$. It is essential for root growth and as a constituent of cell wall materials [5,21]. Replenishing Ca contents in the soils requires liming, which in turn reduces acidity of the soils.

\subsection{Soil Degradation Rating (SDR)/Vulnerability Potential (Vp)}

Seven physicochemical properties namely: texture, $\mathrm{pH}_{(\mathrm{H} 2 \mathrm{O})}$, organic carbon, total nitrogen, available $\mathrm{P}$, effective cation exchange capacity, and percentage base saturation were used as soil quality indicators to assess soil degradation rate (SDR) and vulnerability potential (Vp) of the soils. The soil qualities have varied potential for degradation and vulnerability potential (Vp) of the soils. Based on the selected physicochemical properties, the results (Table 3 ) indicated that texture $(\mathrm{SDR}=3, \mathrm{Vp}=3$ ) showed moderate susceptibility to degradation or vulnerability caused by erosion due to the sandy nature of the soils. The SDR/Vp of soil $\mathrm{pH}_{(\mathrm{H} 2 \mathrm{O})}(4 / 2)$ indicated severe degradation or vulnerability as such level of $\mathrm{pH}$ hinders nutrient uptake by plants. The SDR/Vp weighted value for organic carbon (1/5) and total nitrogen (3/3) showed very low and medium degradation or vulnerability; an indication that the soils contain a good amount of organic matter for any intensive crop production. The SDR/Vp of

Table 3. Rating scheme for soil degradation rates (SDR) and vulnerability potential of selected soil quality indicators.

\begin{tabular}{ccccc}
\hline Parameters & Mean & SDR & Vp & SDR/Vp \\
\hline $\mathrm{pH}_{(\mathrm{H} 2 \mathrm{O})}$ & 5.1 & 4 & 2 & $4 / 2$ \\
Texture & $\mathrm{sl}$ & 3 & 3 & $3 / 3$ \\
Organic C. $\left(\mathrm{gkg}^{-1}\right)$ & 43.09 & 1 & 5 & $1 / 5$ \\
Total N. $\left(\mathrm{gkg}^{-1}\right)$ & 2.54 & 3 & 3 & $3 / 3$ \\
Avail. P. $\left(\mathrm{mgkg}^{-1}\right)$ & 22.14 & 2 & 4 & $2 / 4$ \\
ECEC $\left(\mathrm{cmol}^{-1} \mathrm{~kg}^{-1}\right)$ & 9.99 & 3 & 3 & $3 / 3$ \\
BS $(\%)$ & 65 & 2 & 4 & $2 / 4$ \\
\hline
\end{tabular}

NB: 1 = none, 2 = slight, 3 = moderate, 4 = severe, 5 = extreme for SDR; 5 = none, 4 = low, 3 = moderate, 2 = high, 1 = very high for Vp; Ratings based on mean soil quality and criteria limits (Lal, 1994, Akpan-Idiok, 2012); SDR = Soil degradation rate, $\mathrm{Vp}=$ Vulnerability potential.
2/4 for available $\mathrm{P}$ showed considerable concentration of available $\mathrm{P}$ in the soils. The SDR/Vp of base saturation (2/4) indicated the saturation of soil exchange complex with basic cations and subsequent release of the ions into soil solution for plant absorption. Based on the principle that "good soil quality has least SDR and poor soil quality has the highest SDR and vice versa for Vp", the better soil quality indicators were organic carbon, available $\mathrm{P}$ and base saturation in the soils.

\subsection{Management Strategies of the Soils}

The Obudu Cattle Ranch soils have sandy loam texture and are high in organic carbon, available $\mathrm{P}$ and base saturation. Meanwhile, to avoid a decrease in soil fertility, the following management measures should be practiced:

According to statistics provided by Al-amin, 2007 [1] for the soils of Obudu Cattle Ranch, there has been an increase in the use of land for recreation (5\% - 20\%) and residence (5\% - 15\%), and a subsequent decrease in its use for agricultural purposes (55\% - 40\%) between 1987 and 2007. For this reason, crop rotation should be practiced where restorative crops (legumes) will be sequentially alternated with exhaustive crops (cereals, tubers) on the same piece of land.

Liming of the Soils: Acidity of the soils can be ameliorated by liming. Liming supplies $\mathrm{Ca}$ and $\mathrm{Mg}$, and eliminates $\mathrm{Al}^{3+}$ in soil solution, which is the reason for the high exchangeable acidity in the soils. Crops such as cassava, beans, peanuts, mustards, cabbage, spinach, lettuce, tomato and cucumber thrive well at $\mathrm{pH}$ range of 5.5 to 6.5 at which most soil nutrients exist in ionic forms in soil solution for crop absorption. Application of about 0.5 to 1.0 tonne/ha of lime to the plough layer of $15 \mathrm{~cm}$ depth can ameliorate the acidic condition of the soils and would promote crop yields [4].

Planting of Acid Tolerant Crops: For increased yield, acid tolerant crop species should be planted. The newly improved varieties of cassava produced by International Institute for Tropical Agriculture (IITA) have been found to yield between 32 and 38 tonnes per hectare. Among the cassava varieties are 98/0505, TME 419, 30572, 98/ 0510, 98/0581, 4(2) 142 [22].

Soil Conservation Measures: The steep nature of the landscape coupled with high rainfall and sandy texture encourages erosion which is enhanced by human activities such as destruction of vegetation cover, fuel wood collection, bush burning and the grading of these soils mostly in the same direction with the slope. Low populated areas with enough land should therefore encourage bush fallowing (with leguminous crops), cover cropping and the use of organic matter, plant residues and deep ploughing to improve soil moisture storage and reduce erosion. 


\section{Conclusion}

The study highlights the physicochemical properties of Obudu Cattle Ranch soils in Cross River State, Nigeria. The soils are characterized by a dominant textural class of sandy loam, strongly acid in reaction, high contents of organic carbon, available $\mathrm{P}$ and percentage base saturation as well as moderate contents of total nitrogen and effective cation exchange capacity. With the low to moderate soil degradation rate and vulnerability potential values for the above stated parameters except for base saturation and organic carbon that had low and very low soil degradation rate and low vulnerability potentials, the soils generally are of good quality. The management strategies of the soils for crop production therefore include the following: liming to neutralize the soil acidity, planting of acid tolerant crops and adoption of cultural conservative practices to check erosion and maintain soil fertility.

\section{REFERENCES}

[1] A. Al-Amin, "Ecological and Landscape Issues in Highland Tourism: Comparison of Situations between Wengen of Switzerland and Obudu of Nigeria,” Nigerian Defence Academy, Kaduna, 2007.

[2] B. N. Ekwueme, "Structural Orientations and Precambria Deformational Episodes of Uwet Area, Oban Massif, SE Nigeria,” Precambrian Research, Vol. 34, 1986, pp. 269-289.

[3] F. A. Ushie, "Chemical and Mineralogical Deterioration of Basement Schists in Parts of Obudu Plateau, Southeastern Nigeria,” Journal of Basic Physical Research, Vol. 3, No. 1, 2012, pp. 17-23.

[4] R. Lal, "Tillage Effects on Soil Degradation, Soil Resilience, Soil Quality and Sustainability,” Soil and Tillage Research, Vol. 27, No. 1-4, 1993, pp. 1-8.

[5] A. U. Akpan-Idiok, "Physicochemical Properties, Degradation Rate and Vulnerability Potential of Soils Formed on Coastal Plain Sands in Southeast, Nigeria,” International Journal of Agricultural Research, Vol. 7, No. 7, 2012, pp. 358-366.

[6] A. L. Tukur, A. A. Adebayo and M. Galtima, “The Land and People of the Mambilla Plateau,” Heinemann Educational Books (Nigeria), Ibadan, 2005, p. 149.

[7] J. Hurault, "Land Crisis on the Mambila Plateau of Nigeria, West Africa,” Journal of Biogeography, Vol. 25, No. 2, 1998. pp. 285-299.

http://onlinelibrary.wiley.com/doi/10.1046/j.1365-2699.1 998.252244.x/abstract

[8] R. R. Ipinmoroti, G. O. Iremiren, O. Olobamiwa, A. O. Fademi and E. O. Aigbeken, "Effects of Inorganic and Organic Based Fertilizers on Growth and Performance of
Tea and Cost Implications in Kusuku, Nigeria,” Proceedings of the 9th African Crop Science Conference, 28 September-1 October 2009, Cape Town, 2009, pp. 247-250.

[9] E. U. Udo, “Geography of West Africa,” George Harap and Co., London, 1978, p. 126.

[10] Bulktrade Investment Company Limited, "Soil Land Use Survey of Cross River State, Nigeria,” Ministry of Agriculture and Natural Resources, Calabar, 1989, p. 376.

[11] A. S. R. Juo, "Selected Method for Soil and Plant Analysis,” International Institute of Tropical Agriculture (IITA), Ibadan, 1979.

http://library.wur.nl/isric/index2.html?url=http://library.w ur.nl/WebQuery/isric/4391

[12] A. Walkley and I. A. Black, “An Examination of the Degtjareff Method for Determining Soil Organic Matter and a Proposed Modification of the Chromic Acid Titration Method,” Soil Science, Vol. 37, No. 1, 1934, pp. 29-38.

[13] R. H. Bray and L. T. Kurtz, "Determination of Total, Organic and Available Forms of Phosphorus in Soils," Soil Science, Vol. 59, No. 1, 1945, pp. 39-46.

[14] C. A. Black, D. D. Evans, J. L. White, L. E. Ensminger and F. E. Clark, "Methods of Soil Analysis,” Part 2: Chemical and Microbiological Properties. American Society of Agronomy, Madison Inc., Madison, Wisconsin, 1569, p. 1569.

[15] E. O. McLean, "Aluminium: Methods of Soil Analysis Part 1,” American Society of Agronomy, Vol. 1, 1965, pp. 978998.

[16] A. Essoka, I. Ibanga and U. Amalu, "Physical Properties of the Mountain Soils of Cross River State, Nigeria," Nigerian Journal of Soil Science, Vol. 19, No. 2, 2009, pp. 1597-4488.

[17] W. O. Enwenzor, E. J. Udo, N. J. Usoroh, K. A. Ayotade, J. A. Adepetu, V. A. Chude and C. I. Udegbe, "Fertilizer Use and Management for Crops in Nigeria,” FPDD, Federal Ministry of Agriculture, Water Resources and Rural Development, Lagos, 1989, p. 163.

[18] FPDD, "Literature Review on Soil Fertility Investigations in Nigeria,” Lagos, Fertilizer Procurement and Distribution Division, Federal Ministry of Agriculture and Natural Resources, 1990.

[19] E. A. Paul and F. E. Clark, "Soil Microbiology and Biochemistry,” Academic Press, San Diego, 1989.

[20] J. R. Landon, "Booker Tropical Soil Manual: A Handbook for Soil Survey and Agricultural Land Evaluation in the Tropics and Subtropics,” Booker Tate Ltd., England, 1991.

[21] E. Epstein, "Mineral Nutrition of Plants: Principles and Perspectives," Whitley, New York, 1972.

[22] J. O. Shiyam, B. F. D. Oko, A. E. Uko, H. D. Uket and N. E. Ekanem, “Agronomic Evaluation of Some Elite Cassava Genotypes in the Rain Forest Agroecology of Southeastern Nigeria,” Continental Journal of Agronomy, Vol. 1, No. 1, 2007, pp. 1-4. 